\title{
Catechin: Molecular Mechanism of Anti-Cancer Effect
}

\author{
Katekin: Mekanisme Molekular Efek Antikanker \\ Liza Meutia Sari \\ Department of Oral Medicine, \\ Faculty of Dentistry, Universitas Syiah Kuala, \\ Jl. Teuku Nyak Arief, Darussalam, Banda Aceh, \\ E-mail: lizameutiasari@unsyiah.ac.id
}

\begin{abstract}
Over the recent decade, attention have been focused on the pathologic role of free radicals in a variety of diseases, which are most related to carcinogenesis process. Carcinogenesis is a multi-step process that is induced primarily by carcinogens leading to the development of cancer. Extensive research in the last few years has revealed that regular consumption of certain fruits and vegetables can reduce the risk of acquiring specific cancers. Catechins are phytochemical compounds found in high concentrations in a variety of plant-based foods and beverages. Studies with cell lines have demonstrated that catechins affect signal transduction pathways, inhibit cell proliferation and induce apoptosis. More mechanistic studies in these areas will help us to understand the inhibitory action of catechin against carcinogenesis and provide background for evaluating the effects of catechin on human carcinogenesis.
\end{abstract}

Keywords: Catechin, Carcinogenesis, Cancer prevention

\begin{abstract}
Abstrak
Selama beberapa dekade terakhir, perhatian telah difokuskan pada peran patologis radikal bebas dalam berbagai penyakit, yang paling banyak terkait dengan proses karsinogenesis. Karsinogenesis adalah proses multi-step yang paling banyak diinduksi oleh karsinogen yang mengarah ke perkembangan kanker. Penelitian yang meluas dalam beberapa tahun terakhirmengungkapkan bahwa konsumsi buah dan sayuran secara teratur dapat mengurangi risiko timbulnya kanker tertentu. Katekin adalah senyawa biokimia yang ditemukan dalam konsentrasi tinggi dalam berbagai makanan dan minuman nabati. Penelitian dengan menggunakan galur sel telah menunjukkan bahwa katekin mempengaruhi jalur transduksi sinyal, menghambat proliferasi sel, dan menginduksi apoptosis. Semakin banyak penelitian tentang mekanisme ini dilakukan, maka akan membantu kita untuk memahami aksi hambatan katekin terhadap karsinogenesis dan memberikan latar belakang dalam mengevaluasi efek katekin terhadap karsinogenesis manusia.
\end{abstract}

Kata kunci: Katekin, Karsinogenesis, Pencegahan kanker

\section{INTRODUCTION}

Tumorigenesis is a multistep process that begins with cellular transformation, progresses to hyperproliferation and culminates in the acquisition of invasive potential, angiogenic properties and establishment ofmetastatic lesions. This process can be activated by any one of the various environmental carcinogens (such as cigarette smoke, industrial emissions, gasoline vapours), inflammatory agents (such as tumour necrosis factor and $\mathrm{H}_{2} \mathrm{O}_{2}$ ), tumour promoters (such as phorbol esters and okadaic acid). This multistep process of carcinogenesis consists of three phases: tumour initiation, promotion, and progression phases. ${ }^{1}$ Carcinogenesis is characterized by uncontrolled cell growth and acquisition of metastatic properties. In most cases, activation of oncogenes and/or deactivation of tumour suppressor genes lead to uncontrolled cell cycle progression and inactivation of apoptotic mechanisms. ${ }^{2}$

Chemoprevention, especially through the use of naturally occurring phytochemicals capable of impeding the process of carcinogenesis at one or more steps, is an ideal approach for cancer management. ${ }^{3}$ Cancer chemoprevention, by the use of natural, dietary orsynthetic agents that can reverse, suppress or prevent carcinogenic progression, has become an appealing strategy to combat the dogma associated 
with increasing cases of cancers worldwide. ${ }^{4}$ Extensive research in the last few years has revealed that regular consumption of certain fruits and vegetables can reduce the risk of acquiring specific cancers. Phytochemicals derived from such fruits and vegetables, referred to as chemo preventive agents include genistein, resveratrol, diallyl sulfide, S-allyl cysteine, allicin, lycopene, capsaicin, curcumin, 6gingerol, ellagic acid, ursolic acid, silymarin, catechins, and eugenol. ${ }^{5}$ One of the phytochemical compounds that currently have an important role as an antioxidant is catechins. Catechins are a group of polyphenolic compounds belonging to flavonoid class present in high concentrations in a variety of plant-based fruits, vegetables, and beverages. ${ }^{6}$ Many research articles have established that in vitro studies of catechins have the potential to impact a variety of human diseases. ${ }^{7}$ The beneficial effect of catechins is reported in the treatment of cancer, cardiovascular diseases, diabetes, neurodegenerative diseases, and liver diseases. ${ }^{8}$ Apparently, catechins have function not only as powerful antioxidant, ${ }^{9}$ preventing oxidative damage in healthy cells, ${ }^{10}$ but also as an antiangiogenic, antitumor agent, ${ }^{11}$ and a modulator of tumor cell response to chemotherapy. ${ }^{12}$ It can induce apoptosis by increasing caspases ${ }^{13}$ and promotes cell growth arrest by altering the expression of cell cycle regulatory proteins. ${ }^{14}$ This review describes the molecular mechanism of catechins as a non-toxic natural agent in preventing the tumour progression and /or treatment of human malignancies.

Sources and structure of catechins Polyphenols are the most abundant antioxidants in our diets. The main classes ofpolyphenols are phenolic acids (mainly caffeic acid) and flavonoids (the most abundant in the diet areflavanols (catechins plus proanthocyanidins), anthocyanins and their oxidation products), which account for one- and two-thirds, respectively. ${ }^{15}$ Catechins are the main flavanols, which are very abundant in tea. Young shoots contain 200340 mgof catechin, gallocatechin and their galloylated derivatives per gram of dry leaves. ${ }^{15}$ Frequent consumption of tea, an important source of both flavanols and flavonols, has been correlated with a lower incidence of cancer of the breast, prostate, bladder, lung, pancreas, colon, stomach, oesophagus, and oral cavity. ${ }^{16}$

The term catechins are commonly used to refer the family of flavonoids and the subgroup flavan-3-ols or simply, flavanol. Catechins are differentiated from the ketone-containing flavonoids such as quercetin and rutin, which are called flavonols. High concentrations of catechin can be found in fresh tea leaves, red wine, broad beans, black grapes, apricots, and strawberries. ${ }^{6}$ Green tea has attracted significant attention recently, both in the scientific and in consumer communities for its health benefits for a variety of disorders, ranging from cancer to weight loss. The beneficial effects of green tea are attributed to the polyphenolic compounds present in green tea, particularly the catechins, which make up 30\% of the dry weight of green tea leaves. ${ }^{17}$ Also, epicatechin concentrations are high in apples, blackberries, broad beans, cherries, black grapes, pears, raspberries, and chocolate (Table. 1).

Table 1. Sources of catechin widely distributed in food 6

\begin{tabular}{lll}
\hline Food & $\begin{array}{l}\text { Catechins } \\
\text { (mg/100g) }\end{array}$ & $\begin{array}{l}\text { Catechins } \\
\text { (mg/serving) }\end{array}$ \\
\hline Apple & $10-43$ & $20-86$ \\
Apricot & $10-25$ & $20-50$ \\
Beans & $35-55$ & $70-110$ \\
Black tea & $6-50$ & $12-100$ \\
Blackberry & $9-11$ & $9-11$ \\
Cherry & $5-22$ & $10-44$ \\
Chocolate & $46-61$ & $23-30$ \\
Cider & 4 & 8 \\
Grape & $3-17.5$ & $6-35$ \\
Green tea & $\mathbf{1 0 - 8 0}$ & $\mathbf{2 0 - 1 6 0}$ \\
Peach & $5-14$ & $10-28$ \\
Red raspberry & $2-48$ & $2-48$ \\
Red wine & $8-30$ & $8-30$ \\
Strawberry & $2-50$ & $2-50$ \\
\hline
\end{tabular}

Apples contain a variety of polyphenols including quercetin, catechin, phloridzin and chlorogenic acid, all of which are strong antioxidants. Strawberries were found to contain the most complex mixture of catechins, comprising catechin $(75 \%$ of total catechins), (-) epicatechin-3-gallate (ECG) $18 \%$ of total catechins, (-) epigallocatechin (EGC) 5\% of total catechins, and(+) gallocatechin (GC) $3 \%$ of total catechins. ${ }^{18}$ There are many vegetables, which are good sources of catechins. Catechins and type B procyanidins have not been found in leafy greens or root vegetables but have been detected in legumes such as broad and green beans. The beneficial effects of green tea are attributed to the polyphenolic compounds present in green tea, particularly the catechins, which make up $30 \%$ of the dry weight of green tea leaves. ${ }^{19}$ Catechins are the major building blocks of tannins when they join, they are also known as procyanidins. These compounds are most common in the seeds and skins of grapes that have not fully ripened. ${ }^{20}$ There are several polyphenolic catechins in green tea, viz. (-) epicatechin (EC), ECG, EGC, (-) epigallocatechin-3-gallate (EGCG), (+) catechin, and GC (Figure 1.). ${ }^{17}$ EGCG, the most abundant catechin in green tea, accounts for $65 \%$ of the totalcatechin content. A cup of green tea may 
contain 100-200 mgof EGCG. Catechin and gallocatechin are present in traceamounts. Most of the medicinal properties of green tea are associated with the epicatechins $(2 R, 3 R)$ rather than the catechins (2S, 3R).

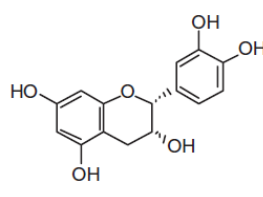

(-) epicatechin (EC)

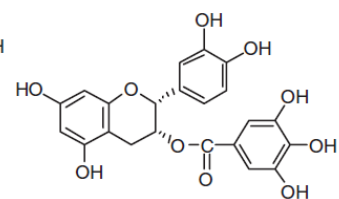

(-) epicatechin gallate (ECG)

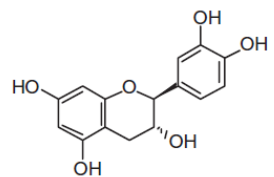

(+) catechin

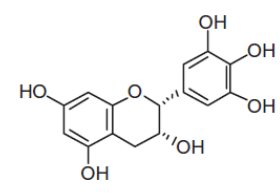

(-) epigallocatechin (EGC)

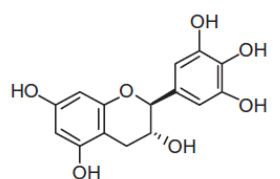

(+) gallocatechin (GC)

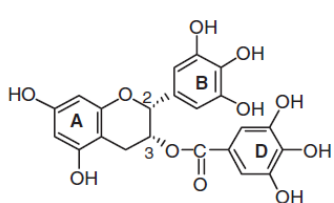

(-) epigallocatechin gallate (EGCG)

Figure 1. Structures of the major polyphenolic catechins present in green tea. ${ }^{6}$

It is well known that oncogene mutation and reactive oxygen species (ROS) play important roles in the cancer initiation stage. Oncogene mutation leads to procarcinogen activation by activating some phase I enzymes such as the cytochrome P450s. ROS actively participate in the metabolic activation of procarcinogens. EGCG can neutralize these procarcinogens by inhibiting the activity of cytochrome P450 enzymes and modulating ROS. Initiation phase, catechins are able to neutralize the procarcinogens by inhibiting the activity of cytochrome P450 enzyme and modulating free radicals. ${ }^{21}$ Wang et al. proved that catechins were able to inhibit the activity of Nicotinamide adenine dinucleotide phosphate (NADPH)-cytochrome c reductase. Mukhtar et al. also claimed that EGCG could interact with hepatic cytochrome $\mathrm{P} 450$ and inhibit the P450-dependent mixed-function oxidase enzymes in skin and liver. ${ }^{22}$ The epicatechin derivative structure is capable in inhibiting microsomal enzyme system derived from the catechin hydroxyl group. ${ }^{23}$ The pyrogallol structure causes catechin molecules to have a strong metal-chelating ability that can bind to metal transition ions and act as preventive antioxidants. Its high affinity for the two layers of lipid cell membrane makes it easier for catechin molecules to enter the nucleus of cancer cells. ${ }^{23}$

The initiation and progression of cancer are related to epigenetic alterations, including aberrant DNA methylation and acetylation. Cancer is modulated by both genetic and epigenetic events. Epigenetic events could alter gene expression without changing the primary DNA sequence, and epigenetic mechanisms include DNA methylation and histone acetylation. These epigenetic changes are involved in the alteration of gene function and expression, lea- ding to a malignant cellular formation. Among various epigenetic modifications, DNA methylationis most extensively studied in mammals. ${ }^{24}$ Hypermethylation on the DNA molecule limits the binding of transcription factors to promoters, resulting in the recruitment of additional silencing-associated proteins and gene silencing. This methylation is mediated by DNA methyltransferase (DNMT) ${ }^{24}$ EGCG has been known as an inhibitor of DNMT by direct inhibitory interaction with the catalytic site of DNMT. The EGCG increases levels of acetylation on lysine of histone $\mathrm{H} 3$ and histoneH4, leading to the up regulation of tumor-suppressor genes,p16INK4a, and Cip1/p21 in skin carcinoma cells. ${ }^{25}$

ROSs are critical signalling molecules that modulate anticancer effects. First, EGCG could directly scavenge ROS. The antioxidant activity of EGCG results from the transfer of hydrogen atom or singleelectron transfer reactions, involving hydroxyl groups of the $\mathrm{B}$ and/or $\mathrm{D}$ rings. The antioxidant effect of EGCG is related to anticancer function. The EGCG reduces cell proliferation and induces apoptosis in low-dose $\mathrm{H}_{2} \mathrm{O}_{2}(10 \mathrm{M})$-treated colon carcinomacells and down regulates 12-O-tetradecanoylphorbol-13-acetate-mediated oxidative stress in cervical carcinomacells. ${ }^{26}$

The cancer promotion stage is a reversible and a long-term process, in which some intracellular signalling pathways and proteins associated with cell cycle are involved. EGCG exerts its anticancer effect by interfering with many signalling pathways and modulating cell cycle. The inhibitory mechanism of the promotion stage is divided into three process, namely the intervention of intracellular signalling pathways, increases the caspase activity, and cell cycle modulation. Yamamoto et al. showed that ca- 
techins inhibit phosphorylation of extracellular signal-regulated protein kinases (ERK)-1 and 2 and suppress the activity of p38MAPKs in human fibrosarcoma cells. ${ }^{27}$ The ERK enzymes are important transducers of proliferation signals. ${ }^{27}$ Alshatwi evaluated the role of catechin hydrate $(\mathrm{CH})$ in suppressing proliferation of MCF-7 cells through TP53/ caspase mediated apoptosis. ${ }^{28} \mathrm{CH}$ exhibits anticancer effects by blocking the proliferation of MCF7cells and inducing apoptosis in part by modulating expression levels of caspase- $3,-8$, and -9 and $553 .^{28}$ The induction of apoptosis by $\mathrm{CH}$ is affected by its ability to regulate the expression of pro-apoptotic genes such ascaspase- $3,-8$, and -9 and $\mathrm{p} 53 .{ }^{28}$ Nakazato et al. found that (-)-Epigallocatechin-3-gallate has potential as a novel therapeutic agent for patients with B-cell malignancies including multiple myeloma via induction of apoptosis mediated by modification of the redox system. In addition, (-)-epigallocatechin-3-gallate enhanced As $2 \mathrm{O} 3$ - induced apoptosis in human multiple myeloma cells. ${ }^{29}$ Most an-ticancer agents have been reported to kill tumour cells by inducing apoptosis via the mitochondrial apoptotic pathway, or via the death receptors. Apoptosis has been known as a key strategy for the elimination of cancer cells. The ratio between anti-apoptotic Bcl-2families (Bcl-2 and $\mathrm{Bcl}-\mathrm{xL}$ ) and proapoptotic Bcl-2 families(Bax and Bak) decides the cellular susceptibility against anticancer drugs in cancer cells. Furthermore, BH3-only proteins (PUMA, Noxa, and Bim) bind with anti-Bcl-2 proteins to inhibit their functions, resulting in induction of apoptosis. EGCG induces apoptosis by the-downregulation of Bcl-2 and/or up-regulation of Bax expression in nasopharyngeal carcinoma cells. ${ }^{30}$ However, another research found that catechin, particularly EGCG, did not modulate the apoptotic pathway, but predominantly induced caspase-independent cell death in accordancewith the necrotic morphology. ${ }^{13}$ The EGCG induced necroticcell death via a caspase-independent mechanism in chronic myelogenous leukemia (CML) celllines, without influencing any aspects of the apoptotic pathway. ${ }^{13}$ Katunuma et al. reported that the tea-catechin derivatives are shown to inhibit activities of caspases-3, 2 and 7 in vitro, and prevented experiment alapoptosis at the cell and animal levels. Epigallocatechin-gallateshowed the strongest inhibition to these caspases, but cysteine cathepsins and caspase- 8 were not inhibited. ${ }^{31}$

Catechins can also inhibit the cell cycle. The cell cycle is controlled by numerous mechanisms ensuring correct cell division. ${ }^{32}$ The mechanisms are regulation of cyclin-dependentkinases (CDK) by cyclins, CDK inhibitors and phosphorylating events. ${ }^{32}$
Cell-cycle dysregulation is a hallmark of tumor cells. The ability of normal cells to undergo cell-cycle arrest after damage to DNA is crucial for the maintenance of genomicintegrity. ${ }^{33}$ The biochemical pathways that stop the cellcycle in response to cellular stressors are called checkpoints. Defective checkpoint function results in genetic modifications that contribute to tumorigenesis. The regulation of checkpoint signalling also has important clinical implycations because the abrogation of checkpoint function can alter the sensitivity of tumour cells to chemotherapeutics. Mayr et al. evaluated the cytotoxic effect of EGCG alone or in combination with cisplatin on eight BTC cell lines. The EGCG reduced the mRNA levels of various cell cycle-related genes while increasing the expression of the cell cycle inhibitor p21 and the apoptosis-related death receptor $5 .^{34}$ This observation was accompanied by an increase in caspase activity and cells in thesub-G1 phase of the cell cycle, indicating induction of apoptosis. EGCG also induced a down-regulation of expression of stem cell-related genes and genes that are associated with an aggressive clinical character of the tumour, such ascd133 and abcg2. ${ }^{34}$ The function of catechin is also related to cell cycle modulation in the cancer cell. Nihal et al. showed that catechins can inhibit Cdk1 and Cdk2 activities as well as CKI initiation such as p16, p21, and p27 in melanoma. ${ }^{35}$ Kavanagh et al. found that p27 capable of stopping in the $G_{1} / S$ phase could be induced by catechins in breast cancer. ${ }^{36}$ Another study reported by Hastak et al. showed that catechins were able to block the cell cycle, especially in the dependent p53 pathway which involved the function of p21 and Bax in prostate carcinoma cells. ${ }^{37}$ Mayr et al. reported a reduction in regulatory genes triggering cell cycle such as ccna2, ccnbl, cendl, and e2fl due to catechin administration, whereas p21 expression which was a cell cycle inhibitor and also dr5 gene associated with apoptosis increased. $^{34}$ This condition affected mRNA expression followed by increased activity caspase, subG1 population (an indication of apoptosis), decrease in population $\mathrm{G}_{2} / / \mathrm{M}$ (an indication of cell cycle arrest) in bladder cancer cells. ${ }^{34}$

Carcinogenesis involves uncontrolled cell growth, which follows the activation of oncogenes and/or the deactivation of tumour suppression genes. Metastasis requires down-regulation of cell adhesion receptors necessary for tissue-specific, cell-cell attachment, as well as up-regulation of receptors that enhance cell motility.Inhibition of migration and invasion of tumor cells could be a target of anticancer therapy. Catechin resistance at the stage of cancer progression is its role in inhibiting MMP. This enzyme is a protease that can degrade almost all com- 
ponents of the extracellular matrix. Catechins are able to inhibit MMP-2 and MMP-9 in endothelial cells. ${ }^{38}$ MMP-2 and MMP-9 secretion is elevated in several types of human cancers and their elevated expression has been associated with poor prognosis. Expression of MMPs is highly regulated by cytokines and signal transduction pathways, including those activated by phorbol 12-myristate 13-acetate (PMA). ${ }^{38}$

Angiogenesis, the development of new capillaries from pre-existing blood vessels, is required in physiological processes such as wound healing and pathological conditions including tumour growth and metastases. Tumour angiogenesis is a complex process that consists of several steps including the secretion of angiogenic factors by tumour and host cells, activation of proteolytic enzymes, endothelial cell migration, invasion, endothelial cell proliferation, and capillary formation. Vascular endothelial growth factor (VEGF) and its receptors have been known as the important angiogenic factors and are commonly over expressed in several types of human cancers. Catechins especially EGCG is proved to inhibit tumour growth and angiogenesis by the down-regulation of VEGF expression in serumdeprived HT29 human colon cancer cells. ${ }^{39}$ Leong et

\section{REFERENCES}

1. Dorai T, Aggarwal BB. Role of chemopreventive agents in cancer therapy. Cancer Lett 2004; 215: 129-40.

2. Sarkar S, Horn G, Moulton K, Oza A, Byler S, et al. Cancer development, progression, and therapy: an epigenetic overview. Int. J. Mol. Sci. 2013; 14: 21087-113.

3. Riady I, Mohamed H, Rady M, Siddiqui IA, and Mukhtar H. Cancer preventive and therapeutic effects of EGCG, the major polyphenol in green tea. EJBAS 2018; 5:1-23

4. Batra P, Sharma AK. Anti-cancer potential of flavonoids: recent trends and future perspectives. Biotech 2013; 3: 439-59.

5. Nijveldt RJ, Nood EV, Van Hoorn D, Boelens PG, Van Norren K, et al. Flavonoids: a review of probable mechanisms of action and potential applications. Am J Clin Nutr 2001; 74: 418-25.

6. Gadkari PV, Balaramana M. Catechins: Sources, extraction and encapsulation: a review. Food Bioprod Process 2014; 30:1-17.

7. Velayutham P, Babu A, and Liu D. Green tea catechins and cardiovascular health: an update. Curr Med Chem 2008; 15(18): 1840-50.

8. Min KJ, and Kwon TK. Anticancer effects and molecular mechanisms of epigallocatechin-3-gallate. IMR 2014; 3: 16-24. al. also found that green tea extract inhibits angiogenesis partly through the disruption of STAT3-mediated transcription of genes, including VEGF. ${ }^{40}$ Several members of the signal transducers and activators of transcription (STAT) family play a role in tumorigenesis. The STAT3 activity is commonly upregulated in breast cancer and regulates the expression of angiogenic genes including VEGF and MMP9. ${ }^{40}$

\section{CONCLUSION}

This review presents evidence that catechins can be used not just to prevent cancer but also to treat cancer because of their effects in the initiation, promotion, and progression stages. Catechins, especially EGCG promotes anticancer effects by modulation of multiple processes, including inhibition of carcinogen activity, tumorigenesis, proliferation, apoptosis induction, cell cycle arrest, metastasis, and angiogenesis. Based on the molecular mechanisms of the EGCG-induced anti-cancer effect, further studies are needed to define the use of catechins in clinical treatment.

\section{Conflict of interest}

The author declares no conflicts of interest.
9. Lambert JD, and Elias RJ. The antioxidant and prooxidant activities of green tea polyphenols: A role in cancer prevention. Arch Biochem Biophys 2010; 501: 65-72.

10. Roychoudhury S, Agarwal A, Virk G, and Cho CL. Potential role of green tea catechins in the management of oxidative stress-associated infertility. Reprod Biomed online 2017; 34(5): 487-98.

11. Ren W, Qiao Z, Wang H, Zhu L, and Zhang L. Flavonoids: promising anticancer agents. Med Res Rev 2003; 23(4): 519-34.

12. Shimizu M, Shirakami Y, Sakai H, Kubota M, Kochi T, et al. Chemopreventive potential of green tea catechins in hepatocellular carcinoma. Int $\mathbf{J}$ Mol Sci 2015; 16(3): 6124-39.

13. Iwasaki R, Ito K, Ishida T, Hamanoue M, Adachi S, et al. Catechin, green tea component, causes caspase independent necrosis-like cell death in chronic myelogenous leukemia. Cancer Sci 2009; 100(2): 349-56.

14. Khiewkamrop P, Phunsomboon P, Richert L, Pekthong D, and Srisawang P. Epistructured catechins, EGCG and EC facilitate apoptosis induction through targeting de novo lipogenesis pathway in HepG2 cells. Cancer Cell Int 2018; 18(46): $1-13$.

15. Tapiero H, Tew KD, Ba GN, and Mathé G. Polyphenols: do they play a role in the prevention of 
human pathologies? Biomed Pharmacother 2002; 56: 200-07.

16. Brusselmans K, Vrolix R, Verhoeven G, and Swinnen JV. Induction of cancer cell apoptosis by flavonoids is associated with their ability to inhibit fatty acid synthase activity. J Biol Chem 2005; 280(7): 5636-45.

17. Zaveri NT. Green tea and its polyphenolic catechins: Medicinal uses in cancer and noncancer applications. Life Sci 2006; 78: 2073-80.

18. Yamamoto M, Nakatsuka S, Otani H, Kohmoto K, Nishimura S. (+)-Catechin acts as an infectioninhibiting factor in strawberry leaf. Phytopathol 2000; 90: 595-600.

19. Khalaf NA, Shakya AK, Al-Othman A, El-Agbar Z, and Farah H. Antioxidant activity of some common plants. Turk J Biol 2008; 32: 51-55.

20. Yilmazer-Musa M, Griffith AM, Michels AJ, Schneider E, and Frei B. Grape seed and tea extracts and catechin 3-gallates are potent inhibitors of alphaamylase and alpha-glucosidase activity. J Agric Food Chem 2012; 60: 8924-29.

21. Chen L, Zhang HY. Cancer preventive mechanisms of the green tea polyphenol (-)-epigallocatechin-3gallate. Molecules 2007; 12: 946-57.

22. Mukhtar H, Wang ZY, Katiqan SK, Agarwal R. Tea components: antimutagenic and antigagenic effects. Prev Med 1992; 21: 351-60.

23. Misaka S, Kawabe K, Onoue S, Werba JP, Giroli M, et al. Effects of green tea catechins on cytochrome p450 2B6, 2C8, 2C19, 2D6, and 3A activities in human liver and intestinal microsomes. Drug Metab Pharmacokinet 2013; 28(3): 244-49.

24. Wajed SA, Laird PW, DeMeester TR. DNA methylation: an alternative pathway to cancer. Ann Surg 2001; 234(1): 10-20.

25. Nandakumar V, Vaid M, Katiyar SK. (-)-Epigallocatechin-3-gallate reactivates silenced tumor suppressor genes. Cip1/p21 and p16INK4a, by reducing DNA methylation and increasing histones acetylation in human skin cancer cells. Carcinogenesis 2011;32:537-44.

26. Park IJ, Lee YK, Hwang JT, Kwon DY, Ha J, Park OJ. Green tea catechin controls apoptosis in colon cancer cells by attenuation of $\mathrm{H} 2 \mathrm{O} 2$-stimulated COX-2 expression via the AMPK signaling pathway at low-dose $\mathrm{H} 2 \mathrm{O} 2$. Ann N Y Acad Sci 2009; 1171: 538-44.

27. Maeda-Yamamoto M, Suzuki N, Sawai Y, Miyase T, Sano M, et al. Association of suppression of extracellular signal-regulated kinase phosphorylation by epigallocatechin gallate with the reduction of matrix metalloproteinase activities in human fibrosarcoma HT1080 cells. J Agric Food Chem 2003; 51: 1858-63.

28. Alshatwi AA. Catechin hydrate suppresses MCF-7 proliferation through TP53/Caspase-mediated apoptosis. J Exp Clin Canc Res 2010;29(167):1-9.

29. Nakazato T, Ito K, Ikeda Y, and Kizaki M. Green Tea Component, Catechin, Induces Apoptosis of
Human Malignant B Cells via Production of Reactive Oxygen Species Clin Cancer Res 2005;11(16):6040-49.

30. Zhao Y, Yang LF, Ye M, Gu HH, and Cao Y. Induction of apoptosis by epigallocatechin-3-gallate via mitochondrial signal transduction pathway. Prev Med 2004;39:1172-79.

31. Katunuma N, Ohashia A, Sanoa E, Ishimarub N, Hayashib Y, and Murata E. Catechin derivatives: Specific inhibitor for caspases-3, 7 and 2, and the prevention of apoptosis at the cell and animal levels FEBS Lett 2006;580:741-46.

32. Vermeulen K, Berneman ZN, Van Bockstaele DR. Cell Cycle and Apoptosis. Cell Prolif 2003;36(3):165-75.

33. Stewart ZA, Westfall MD, and Pietenpol JA. Cellcycle dysregulation and anticancer therapy. Trends Pharmacol Sci 2003;2(3):139-45.

34. Mayr C, Wagner A, Neureiter D, Pichler M, Jakab $\mathrm{M}$, et al. The green tea catechin epigallocatechin gallate induces cell cycle arrest and shows potential synergism with cisplatin in biliary tract cancer cells. BMC Complement Altern Med 2015;15(194):1-7.

35. Nihal M, Ahmad N, Mukhtar H, Wood GS. Antiproliferative and proapoptotic effects of (-)epigallocatechin-3-gallate on human melanoma: Possible implications for the chemoprevention of melanoma. Int J Cancer 2005;11:513-21.

36. Kavanagh KT, Hafer LJ, Kim DW, Mann KK, Sherr $\mathrm{DH}$, et al. Green tea extracts decrease carcinogeninduced mammary tumor burden in rats and rate of breast cancer cell proliferation in culture. $\mathrm{J}$ Cell Biochem 2001;82:387-98.

37. Hastak K, Agarwal MK, Mukhtar H, Agarwal ML. Ablation of either p21 or Bax prevents p53dependent apoptosis induced by green tea polyphenol epigallocatechin-3-gallate. FASEB J 2005;19:789-91.

38. Fassina G, Vene R, Morini M. Mechanisms of inhibition of tumor angiogenesis and vascular tumor growth by epigallocatechin-3-gallate. Clin Cancer Res 2004;10:4865-73.

39. Jung YD, Kim MS, Shin BA, Chay KO, Ahn BW, Liu W, et al. EGCG, a major component of green tea, inhibits tumour growth by inhibiting VEGF induction in human colon carcinoma cells. $\mathrm{Br} \mathrm{J}$ Cancer 2001;84:844-50.

40. Leong H, Mathur PS, Greene GL. Green tea catechins inhibit angiogenesis through suppression of STAT3 activation. Breast Cancer Res Treat 2009; 117(3): 505-15 